Eur. J. Clin. Chem. Clin. Biochem.

Vol. 30, 1992, pp. 607-614

(C) 1992 Walter de Gruyter \& Co.

Berlin - New York

\title{
Renal Sorbitol, myo-Inositol and Glycerophosphorylcholine in Streptozotocin-Diabetic Rats
}

\author{
By M. Schmolke ${ }^{1}$, E. Schleicher ${ }^{2}$ and W. G. Guder ${ }^{1}$ \\ ${ }^{1}$ Institut für Klinische Chemie, Krankenhaus München-Bogenhausen, Deutschland \\ ${ }^{2}$ Institut für Diabetesforschung, Krankenhaus München-Schwabing, Deutschland
}

(Received February 24/June 30, 1992)

\begin{abstract}
Summary: The polyols, sorbitol and myo-inositol, seem to be involved in the development of diabetic complications of different organs. High concentrations of both polyols were found in kidney medulla in addition to trimethylamines. To investigate the influence of diabetes mellitus on the regulation of both polyols and glycerophosphorylcholine in kidney, these osmolytes were quantitated enzymatically along the corticopapillary axis in untreated, streptozotocin-diabetic and insulin-treated streptozotocin-diabetic rats.
\end{abstract}

In control animals three individual osmolyte patterns were found: a steep gradient of sorbitol in the papilla, increasing amounts of glycerophosphorylcholine from the outer medulla to the papilla, and nearly equal amounts of myo-inositol in the renal medulla, decreasing towards the cortex.

Diabetic rats exhibit an up to fourfold increase of inner medullary sorbitol, whereas myo-inositol was only elevated in the outer medulla. Glycerophosphorylcholine was lowered in the papillary tip and elevated in the outer medulla and cortex.

Insulin treatment reduced sorbitol to a concentration between those of diabetic and control rats, caused a restoration of glycerophosphorylcholine in the papillary tip and outer medulla to control values, and increased cortical myo-inositol.

These data confirm previous in vitro data, which show that papillary sorbitol specifically increases in hyperglycaemic states, thereby counteracting the increased extracellular tonicity due to elevated tissue glucose concentrations. Imbalance of extra- vs intracellular osmolality during insulin treatment may be involved in the pathomechanism of renal papillary necrosis.

\section{Introduction}

The polyols, sorbitol and myo-inositol, are assumed to be involved in the pathomechanisms of diabetic complications. Thus sorbitol accumulation in various cells was shown to correlate with diabetic ophthalmopathy and neuropathy (1). On the other hand a depletion of cellular myo-inositol in nerve cells has been attributed to hyperglycaemia (2).

The role of the polyols in diabetic nephropathy is less clear. As in other tissues, sorbitol is formed from glucose by the action of aldose reductase. This enzyme is present in glomeruli (3) and tubule cells of the renal inner medulla (4).

Beyer-Mears et al. found a sorbitol accumulation in glomeruli of diabetic rats, which was reversed by treatment with an aldose reductase inhibitor (5). Inhibition of sorbitol formation by sorbinil prevented renal hyperperfusion and hyperfiltration in diabetic rats (6). Little is known about changes in renal cortical myo-inositol concentrations under these conditions.

In normal rats, polyol concentrations in the renal medulla are much higher than in cortical structures 
$(7,8)$. Sorbitol forms a steep gradient from the inner medulla to the papillary tip, whereas myo-inositol concentrations were shown to increase from the cortex to the outer medulla, slightly decreasing towards the papilla. In addition, glycerophosphorylcholine and betaine were accumulated in the renal inner and outer medulla $(7-9)$.

It is now well established that these substances act as organic osmolytes involved in intracellular osmo-adaptation of renal medullary cells $(7-9)$. They were shown to be located intracellularly (8) and to fill the "osmotic gap" existing between the intracellular and interstitial space (10). Under experimental conditions, the intracellular content of organic osmolytes changed in parallel with interstitial tonicity, depending on the diuretic state of the animal. A rapid decrease occurred during water and furosemide diuresis $(8,9,11)$, whereas antidiuresis increased inner medullary osmolytes.

Since sorbitol is formed from glucose by the action of aldose reductase, an increase is to be expected under hyperglycaemic conditions, as observed in other organs (1). On the other hand, diuresis due to glucosuria might lead to a decrease in medullary sodium and therefore organic osmolyte content. Chauncey et al. (12) and Grunewald \& Kinne (13) described an increase of inner medullary sorbitol paralleled by an increase in aldose reductase in diabetic rats, but these authors did not measure other osmolytes, and they did not determine the exact intrarenal localization of the observed changes.

The aim of the present study was to extend these studies by the simultaneous determination of glycerophosphorylcholine and myo-inositol in addition to sorbitol in five different kidney sections under diabetic conditions. Furthermore, the effect of insulin treatment on renal organic osmolytes was investigated.

\section{Materials and Methods}

Animals and experimental groups

Experiments were performed on 21 male Sprague-Dawley rats weighing $235-290 \mathrm{~g}$, kept on a standard laboratory diet with free access to tap water. The animals were divided into three groups:

\section{Group 1}

Four untreated control rats.

\section{Group 2}

Eight rats injected with $100 \mathrm{mg} / \mathrm{kg}$ body weight streptozotocin (SIGMA, Deisenhofen, Germany) into the tail vein under light ether anaesthesia on day 0 . From day 1 to day 6 each rat received two daily subcutaneous injections of $5 \mathrm{U}$ pig insulin (Alt-Insulin vom Schwein, Hoechst, Frankfurt, Germany) at 11 a.m. and 10 p.m. Insulin was withdrawn on day 7 and 8 .

\section{Group 3}

Nine rats treated as in group 2, but insulin treatment continued on day 7 and 8 .

All animals were weighed and glucose and ketone bodies monitored daily in urine with teststrips (Ketodiabur 5000, Boehringer Mannheim, Mannheim, Germany).

On the last day of the experiment (day 8), animals were anaesthesized with a single intraperitoneal nembutal injection (CEVA, Paris, France). After laparatomy, urine was obtained by punction of the bladder and centrifuged for $2 \mathrm{~min}$ at $10000 \mathrm{~g}$. The sediment-free supernatant was stored at $-20^{\circ} \mathrm{C}$. Blood was collected from the aorta into an heparinized tube, centrifuged for $15 \mathrm{~min}$ at $2000 \mathrm{~g}$, and the plasma stored at $-20^{\circ} \mathrm{C}$. Both kidneys were excised, washed free from blood with icecold isotonic saline, and immediately processed as described below.

\section{Preparation of homogenates}

Kidneys were placed on a cooled $\left(+4^{\circ} \mathrm{C}\right)$ Petri dish and sliced into papillary tip (IM3), papillary base (IM2), remainder of inner medulla (IM1), outer medulla and cortex, as described previously (8), and stored at $-20^{\circ} \mathrm{C}$. Each slice $(3-30 \mathrm{mg}$ fresh weight) was homogenized in $1 \mathrm{ml}$ ice-cold $0.3 \mathrm{~mol} / \mathrm{l}$ $\mathrm{HClO}_{4}$. Between 100 and $300 \mu \mathrm{l}$ of the homogenate were used for protein determination by a modified biuret procedure (8). The remaining 700-900 $\mu \mathrm{l}$ were centrifuged for $5 \mathrm{~min}$ at $10000 \mathrm{~g}$. To hydrolyse glycerophosphorylcholine, an aliquot of $140 \mu \mathrm{l}$ of this supernatant was incubated for $1 \mathrm{~h}$ at $95^{\circ} \mathrm{C}$ (14). Hydrolysed and unhydrolysed supernatants (kept on ice) were neutralized with solid $\mathrm{KHCO}_{3}$.

\section{Analytical procedures}

\section{Glycerophosphorylcholine}

Glycerophosphorylcholine was determined enzymatically using choline kinase ${ }^{1}$ ) as described by Wirthensohn et al. (14), with a detection limit of $4 \mathrm{nmol}$ and a coefficient of variation of $10 \%$ at $0.5-1 \mathrm{mmol} / \mathrm{l}$.

\section{Sorbitol}

Sorbitol was measured enzymatically by sorbitol dehydrogenase ${ }^{1}$ ) as described for xylitol (15) using a kit from Boehringer Mannheim, Mannheim, Germany (cat. No. 670057).

\section{myo-Inositol}

myo-Inositol was determined by an enzymatic method using myo-inositol dehydrogenase. Formed NADH is linked to a colour-forming reaction as described by Dolhofer \& Wieland (16).

\section{Glucose}

Glucose in tissue homogenates was measured enzymatically with a hexokinase ${ }^{1}$ ) method. Blood and urine glucose was determined kinetically on an automated analyser (ACP 5040, Eppendorf, Hamburg, Germany) using glucose dehydrogenase ${ }^{1}$ ) (Merck, Darmstadt, Germany) (17). 


\section{Glycated proteins}

Glycated plasma proteins were measured as furosine in plasma protein hydrolysates using the HPLC procedure described by Schleicher \& Wieland (18).

\section{Urine osmolytes}

Urinary sodium and potassium were determined by flame photometry (Eppendorf AFM 5051, Hamburg, Germany) and osmolality with a freeze point osmometer (Vogel, Gießen, Germany). Creatinine was measured kinetically by the method of Jaffé adapted to the Kone Specific analyser (Kone, Turku, Finland) as described by Hofmann et al. (19).

\section{1) Enzymes:}

Choline kinase: ATP:choline phosphotransferase, EC 2.7.1.32

Glucose dehydrogenase: $\beta$ - $D$-glucose: $\mathrm{NAD}(\mathrm{P})$ 1-oxidoreductase, EC 1.1.1.47

Hexokinase: ATP: $D$-hexose 6-phosphotransferase, EC 2.7.1.1

myo-Inositol dehydrogenase: myo-inositol : NAD 2-oxidoreductase, EC 1.1.1.18

Sorbitol dehydrogenase: $L$-Iditol: NAD 5-oxidoreductase, EC 1.1.1.14

\section{Statistics}

All data are given as means \pm SEM with the number of experiments in parentheses. Statistical significance was tested with the U-test of Wilcoxon, Mann \& Whitney (20). For comparison of body weights of diabetic and insulin treated animals between day 6 and day 7 or day 8 the Wilcoxon matched pair signed rank test was used (20).

\section{Results}

\section{Characterization of animals}

\section{Body weights}

The body weight of control animals continuously increased from day $0(255 \pm 6 \mathrm{~g})$ to day 8 (310 $\pm 11 \mathrm{~g})$. Two days after streptozotocin treatment body weight decreased only slightly and remained nearly constant despite insulin treatment (tab. 1). Withdrawal of insulin during day 7 and 8 in group 2 resulted in a slight, but significant decrease vs day 6 (not shown).

Tab. 1. Characterization of animals.

Body weights, urinary osmolytes, blood glucose and glycated plasma proteins in control, diabetic and insulin-treated diabetic rats (see Materials and Methods). All values are given as means \pm SEM with the number of animals in parentheses. Statistical significance was tested with the U-test of Wilcoxon, Mann \& Whitney (20) at the level of $p<0.05=+$ and ns. = not significant.

\begin{tabular}{|c|c|c|c|c|c|c|}
\hline \multirow[b]{2}{*}{ Group } & \multirow{2}{*}{$\begin{array}{l}\text { Control } \\
\text { I }\end{array}$} & \multirow{2}{*}{$\begin{array}{l}\text { Diabetes } \\
\text { II }\end{array}$} & \multirow{2}{*}{$\begin{array}{l}\text { Diabetes } \\
+ \text { insulin } \\
\text { III }\end{array}$} & \multicolumn{3}{|c|}{ Statistical significance } \\
\hline & & & & I vs II & I vs III & II vs III \\
\hline $\begin{array}{l}\text { Body weight } \\
\text { (g) }\end{array}$ & $\begin{array}{r}310 \\
+\quad 11 \\
(3)\end{array}$ & $\begin{array}{r}248 \\
\pm \quad 7 \\
(9)\end{array}$ & $\begin{array}{r}243 \\
\pm \quad 8 \\
(8)\end{array}$ & + & + & ns. \\
\hline \multicolumn{7}{|l|}{ Blood } \\
\hline $\begin{array}{l}\text { Glucose } \\
\quad(\mathrm{mmol} / \mathrm{l})\end{array}$ & $\begin{array}{c}9.1 \\
- \\
(2)\end{array}$ & $\begin{array}{r}25.0 \\
+\quad 1.9 \\
(8)\end{array}$ & $\begin{array}{c}8.8 \\
+\quad 1.6 \\
(8)\end{array}$ & + & ns. & + \\
\hline $\begin{array}{l}\text { Glycated proteins } \\
\text { (mmol/kg protein) }\end{array}$ & $\begin{array}{r}0.8 \\
\pm \quad 0.1 \\
\text { (3) }\end{array}$ & $\begin{array}{c}1.8 \\
+\quad 0.1 \\
(7)\end{array}$ & $\begin{array}{c}1.4 \\
+\quad 0.2 \\
(8)\end{array}$ & + & ns. & ns. \\
\hline \multicolumn{7}{|l|}{ Urine } \\
\hline $\begin{array}{l}\text { Osmolality } \\
\qquad\left(\text { mosmol } / \mathrm{kg} \mathrm{H}_{2} \mathrm{O}\right)\end{array}$ & $\begin{array}{c}1349 \\
\pm 275 \\
(3)\end{array}$ & $\begin{array}{r}1107 \\
\pm 59 \\
(9)\end{array}$ & $\begin{array}{r}1241 \\
\pm 92 \\
(8)\end{array}$ & ns. & ns. & ns. \\
\hline $\begin{array}{l}\text { Glucose } \\
\quad(\mathrm{mmol} / \mathrm{l})\end{array}$ & $\begin{array}{r}1.0 \\
\pm \quad 0.4 \\
(3)\end{array}$ & $\begin{array}{c}538.1 \\
\pm \quad 8.7 \\
(9)\end{array}$ & $\begin{array}{r}12.4 \\
\pm \quad 3.6 \\
(8)\end{array}$ & + & + & + \\
\hline $\begin{array}{l}\text { Sodium } \\
(\mathrm{mmol} / \mathrm{l})\end{array}$ & $\begin{array}{r}105.0 \\
\pm \quad 16.5 \\
(4)\end{array}$ & $\begin{array}{r}32.4 \\
\pm \quad 4.9 \\
(9)\end{array}$ & $\begin{array}{r}93.6 \\
\pm 15.1 \\
(8)\end{array}$ & + & ns. & + \\
\hline $\begin{array}{l}\text { Potassium } \\
\quad(\mathrm{mmol} / \mathrm{l})\end{array}$ & $\begin{array}{r}90.6 \\
+\quad 30.2 \\
(4)\end{array}$ & $\begin{array}{r}41.6 \\
+\quad 4.9 \\
(9)\end{array}$ & $\begin{array}{r}96.1 \\
\pm 14.1 \\
(8)\end{array}$ & + & ns. & + \\
\hline $\begin{array}{l}\text { Creatinine } \\
(\mathrm{mmol} / \mathrm{l})\end{array}$ & $\begin{array}{r}5.8 \\
+\quad 0.4 \\
\text { (3) }\end{array}$ & $\begin{aligned} & 1.5 \\
& \pm 0.3 \\
&(9)\end{aligned}$ & $\begin{aligned} & 5.4 \\
& \pm 0.4 \\
&(6)\end{aligned}$ & + & ns. & + \\
\hline
\end{tabular}


Tab. 2. Glucose ( $\mathrm{mmol} / \mathrm{kg}$ protein) distribution along the corticopapillary axis.

Kidneys of untreated, diabetic and insulin-treated diabetic rats were sliced in five different sections from the cortex to the papillary tip (see Materials and Methods). After homogenizing each slice with $0.3 \mathrm{~mol} / 1 \mathrm{HClO}_{4}$, centrifuging and neutralizing with solid $\mathrm{KHCO}_{3}$, glucose was determined enzymatically with hexokinase. All values are given as $\mathrm{mmol} / \mathrm{kg}$ protein, mean \pm SEM with the number of animals in parentheses.

Statistical significance was tested with the U-test of Wilcoxon, Mann \& Whitney (20) at the level of $p<0.05=+$ and ns. = not significant.

\begin{tabular}{|c|c|c|c|c|c|c|}
\hline \multirow[t]{2}{*}{ Group } & \multirow{2}{*}{$\begin{array}{l}\text { Control } \\
\text { I }\end{array}$} & \multirow{2}{*}{$\begin{array}{l}\text { Diabetes } \\
\text { II }\end{array}$} & \multirow{2}{*}{$\begin{array}{l}\text { Diabetes } \\
+ \text { insulin } \\
\text { III }\end{array}$} & \multicolumn{3}{|c|}{ Statistical significance } \\
\hline & & & & I vs II & I vs III & II vs III \\
\hline Papillary tip & $\begin{array}{r}21.7 \\
\pm 2.9 \\
(3)\end{array}$ & $\begin{array}{c}329.9 \\
\pm 30.9 \\
(9)\end{array}$ & $\begin{array}{r}52.1 \\
+18.4 \\
(8)\end{array}$ & + & ns. & + \\
\hline Papillary base & $\begin{array}{r}18.6 \\
\pm 1.1 \\
(3)\end{array}$ & $\begin{array}{c}363.1 \\
\pm 49.7 \\
(9)\end{array}$ & $\begin{array}{r}23.4 \\
\pm \quad 3.4 \\
(8)\end{array}$ & + & ns. & + \\
\hline Inner medulla & $\begin{array}{r}14.4 \\
\pm 4.6 \\
(3)\end{array}$ & $\begin{array}{c}344.1 \\
\pm 42.5 \\
(8)\end{array}$ & $\begin{array}{r}16.1 \\
+\quad 5.9 \\
(8)\end{array}$ & + & ns. & + \\
\hline Outer medulla & $\begin{array}{r}5.2 \\
\pm 1.5 \\
(4)\end{array}$ & $\begin{array}{c}119.2 \\
\pm 12.1 \\
(9)\end{array}$ & $\begin{array}{r}10.7 \\
+\quad 3.4 \\
(8)\end{array}$ & + & ns. & + \\
\hline Cortex & $\begin{array}{r}42.7 \\
\pm 1.1 \\
(4)\end{array}$ & $\begin{array}{c}152.4 \\
\pm 12.5 \\
(9)\end{array}$ & $\begin{array}{r}35.8 \\
+\quad 6.1 \\
(8)\end{array}$ & + & ns. & + \\
\hline
\end{tabular}

\section{Urine and blood glucose and glycated proteins}

As expected, diabetic rats showed a marked hyperglycaemia $(25.0 \pm 1.9 \mathrm{vs} 9.1 \mathrm{mmol} / \mathrm{l}$ in control rats $)$ and glucosuria $(538.1 \pm 8.7$ vs $1.0 \pm 0.4 \mathrm{mmol} / \mathrm{l}$ in control rats), which was almost normalized by a $97 \%$ decrease after insulin treatment (tab. 1). In contrast, the concentrations of glycated plasma proteins in diabetic $(1.8 \pm 0.1 \mathrm{mmol} / \mathrm{kg}$ protein) and insulintreated diabetic rats $(1.4 \pm 0.2 \mathrm{mmol} / \mathrm{kg}$ protein $)$ were elevated above that observed in control animals $(0.8 \pm 0.1 \mathrm{mmol} / \mathrm{kg}$ protein). This indicates that the insulin-treated diabetic rats had been in a diabetic metabolic state.

\section{Urinary osmolytes}

The diabetes-induced glucosuria was accompanied by an osmotic diuresis, which was expressed in markedly decreased urinary potassium, sodium and creatinine concentrations (tab. 1). In contrast, diabetic animals had only a slightly lowered urine osmolality. Insulin treatment restored all measured urinary quantities to the values found in untreated control rats (tab. 1).
Tissue contents of organic osmolytes and glucose

\section{Control}

In control animals organic osmolytes showed the same distribution patterns along the corticopapillary axis as described previously (8). Sorbitol exhibited a steep gradient from the inner medulla to the papillary tip, glycerophosphorylcholine from the outer medulla to the papilla, whereas myo-inositol increased from the cortex to the outer medulla then decreased slightly towards papillary tip (fig. 1a-c). Glucose decreased sharply from the cortex $(42.7 \pm 1.1 \mathrm{mmol} / \mathrm{kg}$ protein $)$ to outer medulla $(5.2 \pm 1.5 \mathrm{mmol} / \mathrm{kg}$ protein), followed by a continuous increase towards the papillary tip $(21.7 \pm 2.9 \mathrm{mmol} / \mathrm{kg}$ protein) (tab. 2$)$.

\section{Diabetes mellitus}

In diabetic rats dramatic changes in renal glucose and sorbitol content were observed, whereas glycerophosphorylcholine and myo-inositol were less affected. Glucose drastically increased in all kidney sections

Fig. 1. Distribution of organic osmolytes along the corticopapillary axis.

Kidneys of untreated, diabetic and insulin-treated diabetic rats were sliced in five different sections: cortex, outer medulla, inner medulla, papillary base and papillary tip. After homogenizing each section with $0.3 \mathrm{~mol} / 1 \mathrm{HClO}_{4}$, centrifugation and neutralizing with solid $\mathrm{KHCO}_{3}$, (a) sorbitol, (b) glycerophosphorylcholine and (c) myo-inositol were determined enzymatically in the neutralized supernatant. All values are given as mmol/kg protein, mean \pm SEM with the number of animals in parentheses.

Statistical significance was tested with the U-test of Wilcoxon, Mann \& Whitney (20) at p $<0.05$.

- = control vs diabetes or control vs insulin treatment and

$\boldsymbol{\nabla}=$ diabetes vs insulin treatment. 

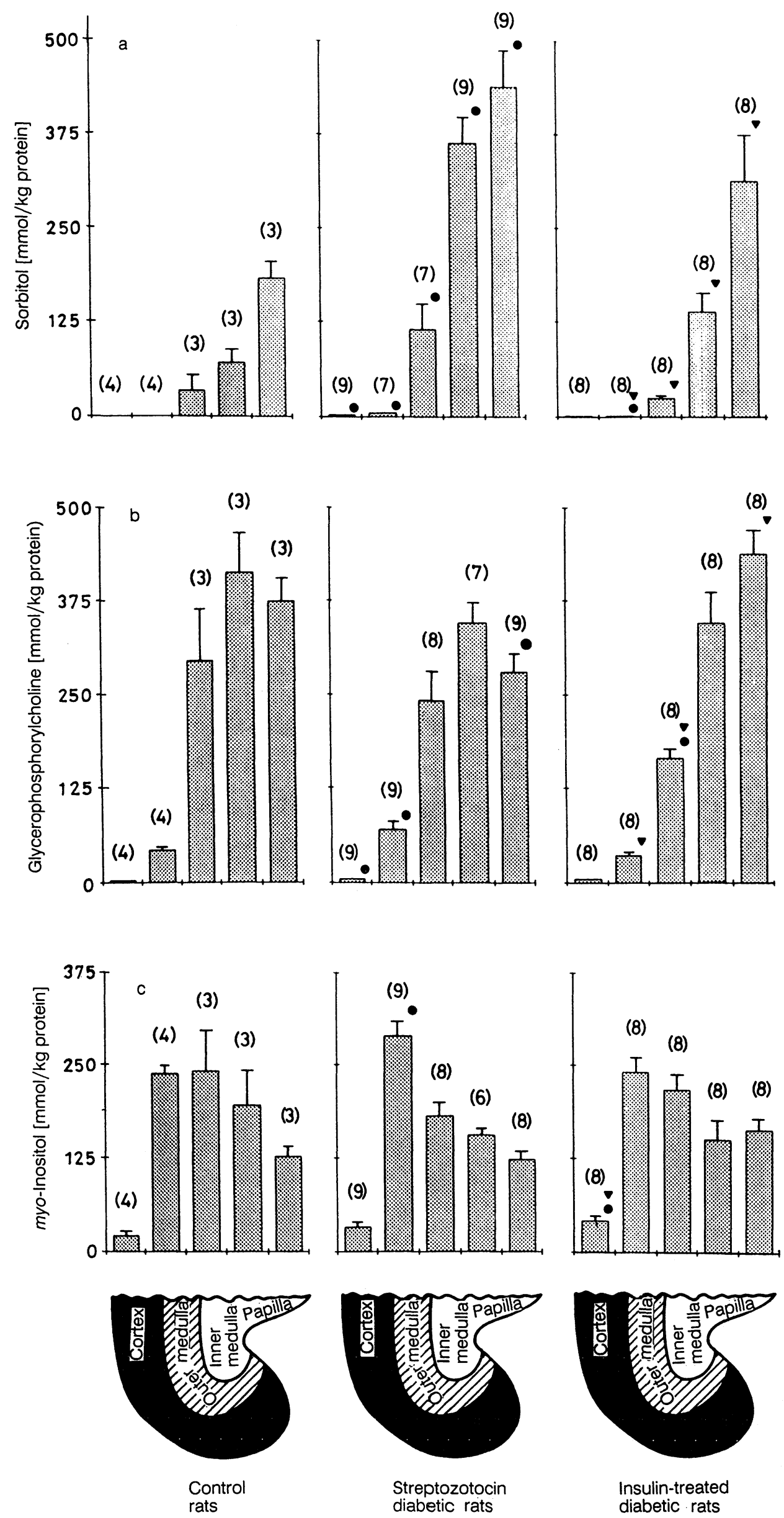
and changed its distribution pattern. No gradient was observed in the inner medulla (329.9 \pm 30.0 to 363.1 $\pm 49.7 \mathrm{mmol} / \mathrm{kg}$ protein), but a steep gradient was seen towards the outer medulla $(119.2 \pm 12.1 \mathrm{mmol} /$ $\mathrm{kg}$ protein) and cortex (152.4 $\mathrm{mmol} / \mathrm{kg}$ protein). The increase was nearly fourfold in the cortex, but more than 15-fold in all medullary structures (tab. 2). The sharp decrease observed in control animals from the cortex to the outer medulla was no longer apparent. However, the threefold increase from the outer to the inner medulla persisted, but at a 20 -fold higher level.

Sorbitol increased 2.5, 5.1 and 3.3-fold in the papillary tip, papillary base and the rest of inner medulla, respectively. In contrast to glucose, no change in the distribution pattern of sorbitol was observed (fig. 1a).

Glycerophosphorylcholine, on the other hand, was slightly decreased in all inner medullary sections, compared with control animals, whereas the outer medulla and cortex showed a significant increase (fig. 1b).

In contrast to these findings, myo-inositol was not affected by the diabetic state of the animal. Only the outer medullary region exhibited an increase $(20 \%)$ in myo-inositol ( $\mathrm{p}<0.05)$ (fig. 1c).

\section{Insulin treatment}

As expected from the observed decrease of urinary and blood glucose, insulin treatment restored the tissue glucose content to control values in all kidney sections, with reappearance of the original profile along the corticopapillary axis. In parallel with urinary glucose, papillary glucose was slightly, but significantly elevated when compared with controls (tab. 2).

Insulin significantly reduced tissue sorbitol concentrations in all layers of the kidney (fig. 1a). In contrast to glucose, however, sorbitol was only partially restored in papillary tissue, remaining 1.6 and 2-fold higher than in the papillary tip and papillary base of control animals, respectively.

Glycerophosphorylcholine showed an opposite behaviour to that of sorbitol after insulin treatment of diabetic rats. In the papillary tip glycerophosphorylcholine was significantly higher than in untreated diabetic rats. No change was found in the papillary base and cortex. In the remaining inner medulla (IM1) and outer medulla insulin treatment led to lower glycerophosphorylcholine contents compared with diabetics rats (fig. 1b). Except for the decrease in the IM1 region, the glycerophosphorylcholine concentrations in insulin-treated diabetic rats were not significantly different from those of control rats.
myo-Inositol was not affected by insulin treatment. Except for a slight, but significant increase of myoinositol in the cortex, the concentrations were comparable to those of control and diabetic animals (fig. 1c).

\section{Discussion}

The present study describes for the first time the behaviour of three organic osmolytes in diabetic and insulin-treated diabetic animals. Sorbitol, myo-inositol and glycerophosphorylcholine were quantitated in five separate kidney sections. Organic osmolytes located intracellularly had been previously measured under diuresis caused by furosemide $(8,9,11)$, water load (9) and lack of endogenous vasopressin production (21). Under these conditions a loss of all organic osmolytes was observed $(8,9,11,21)$, indicating an osmoregulatory role of these substances in the renal medulla.

The results show that each of these substances reacts in a typical and site-specific way to the diuretic state that occurs in diabetes mellitus.

\section{Sorbitol}

The observed increase in renal sorbitol in hyperglycaemic states agrees with the findings of Chauncey et al. (12) and Grunewald \& Kinne (13). The changes shown in the present study are, however, larger than those documented by these authors. This is probably due to the fact that in these earlier studies sorbitol was measured in the total inner medulla (IM1 - IM3). Since the greatest changes in sorbitol concentrations are found in the renal papilla, analysis of total inner medulla can be expected to "dilute" the changes occurring in this subfraction.

These observations point to the physiological function of the so called "polyol pathway", which has often been assumed to be a merely "side effect" of the diabetic state. Our results imply that sorbitol formation in medullary cells may be a useful mechanism for compensating changes in extracellular osmolality caused by glucose. Furthermore, the distribution pattern of aldose reductase in single nephron segments (4) clearly correlates with that of sorbitol as shown in recent microdissection studies (22). Its enzymatic activity increases with diabetes mellitus (13).

The high extracellular glucose in the inner medullary regions seems to be an additional reason for the increase in tubular sorbitol. A threefold increase in tubular sorbitol content was observed in vitro in inner medullary tubule suspensions (8), after increasing extracellular glucose from 5 to $20 \mathrm{mmol} / \mathrm{l}$. 
The observation that continuous insulin treatment over eight days was not sufficient to diminish tubular sorbitol to control values raises the questions about the possible mechanisms of sorbitol depletion by renal inner medullary cells. Enzymatic conversion of sorbitol to fructose by sorbitol dehydrogenase is generally accepted as the metabolic pathway of sorbitol degradation. Interestingly, this enzyme is nearly exclusively found in renal cortex (12), especially in proximal tubules (4), rather than in inner and outer medulla (4). However, when inner medullary tubule suspensions were incubated with media of varying salinity, the sum of tubular and medium sorbitol content remained constant (8). This observation supports the conclusion that sorbitol metabolism does not contribute to any major extent to inner medullary sorbitol depletion. On the other hand, a rapid decrease of intracellular sorbitol (and the other osmolytes) was observed under isotonic conditions in vitro (8). A sorbitol-specific permease has been postulated to regulate intracellular sorbitol concentrations (23). This transporter seems to be controlled by changes in cell volume caused by the variation of extracellular tonicity.

The intermediate tissue sorbitol concentrations in insulin-treated diabetic rats can be explained by assuming two simultaneously acting mechanisms. On the one hand, the decrease in glucose availability after insulin treatment leads to a decrease in sorbitol synthesis that would result in tissue sorbitol concentrations similar to those of control animals. On the other hand, the increasing sodium concentrations, with unchanged urine osmolality, would need a constant level of counteracting intracellular osmolytes. The latter mechanism would keep the osmolality-dependent sorbitol permease unchanged. The observation that the decrease of sorbitol in the papillary tip was counteracted by an increase in glycerophosphorylcholine leads to the interesting question of whether another organic osmolyte compensates the decrease of sorbitol under these circumstances. Such mechanisms are implied by the observation in cultured papillary cells, that decreasing intracellular sorbitol concentrations, due to inhibition of aldose reductase by tolrestat, were compensated by corresponding increase of betaine (24).

\section{Trimethylamines}

The distribution pattern of glycerophosphorylcholine, recognized as organic osmolyte decades ago (25), differs from that of sorbitol; nearly equal concentrations are found in the papillary tip and base, decreasing to $50 \%$ and $5 \%$ in the remaining inner medulla and outer medulla, respectively $(8,9,21)$. Under diabetic conditions, glycerophosphorylcholine concentrations decreased in papillary and increased in outer medullary sections, leading to a change in its distribution pattern. The decrease in the papillary tip in diabetes agrees with the behaviour of this osmolyte in other diuretic states where glycerophosphorylcholine concentrations have been correlated with extracellular urea and sodium concentrations (26). Under in vivo conditions glycerophosphorylcholine concentrations follow those of urinary sodium and urea in water dehydration $(9,26)$, vasopressin treatment of diabetes insipidus rats (21) and sodium loading (27). This osmolyte was assumed to represent the concentrating ability of the entire kidney and to be independent of glucose. This latter assumption was supported by experiments with isolated inner medullary tubules, showing that glucose had no effect on glycerophosphorylcholine concentrations (8). The increasing effect of insulin treatment on papillary glycerophosphorylcholine is also in accordance with this idea, because it increased in parallel with urinary urea and sodium.

The elevated glycerophosphorylcholine concentrations in the outer medulla in the diabetic state point to a different function of the cells in this kidney region. Since this section consists of several tubular segments with individual functions, no functional correlation can be discussed at present.

\section{myo-Inositol}

Cellular myo-inositol depletion has been discussed as a pathogenetic mechanism in diabetic neuropathy (2) and nephropathy (5). The lack of significant changes in the present study does not accord with this concept, but confirms recent findings of Loy et al. (28). In the cortex, myo-inositol was increased rather than decreased, whereas no change was found in all medullary sections. In contrast to sorbitol and glycerophosphorylcholine, myo-inositol seems to be taken up from the extracellular space into the tubular cells. A sodium-dependent uptake mechanism has been described in cortical and outer medullary tubules (29). In conclusion the increase in cortical myo-inositol may be caused by the increase of plasma myo-inositol observed under diabetic conditions by Dolhofer \& Wieland (16).

The relative constancy of myo-inositol concentrations during osmoregulatory changes was also observed during vasopressin treatment of diabetes insipidus rats (21), water deprivation $(8,11,30)$, and after inhibition of aldose reductase by sorbinil in normal and antidiuretic rats (30). The different distribution pattern of myo-inositol, with the highest concentrations in the 
outer medullary region, points to a different tubular localization, which has recently been confirmed by microdissection (22). The thick ascending limbs have been shown to contain high concentrations of myoinositol but not sorbitol, whereas both polyols are present in the inner medullary collecting ducts.

The lack of changes in medullary myo-inositol in diabetes mellitus and insulin treatment indicates that this osmolyte does not play a major role in the reg- ulation of the renal concentrating mechanism, and is not responsible for renal diabetic complications under these conditions.

\section{Acknowledgement}

The authors thank Mrs. Sigrid Lefrank and Mrs. Evi Wagner for the skilfull technical assistance. This work was supported by the Deutsche Forschungsgemeinschaft Projekt Gu 82/3-2.

\section{References}

1. Burg, M. B. \& Kador, P. F. (1988) Sorbitol, osmoregulation, and the complications of diabetes. J. Clin. Invest. 81, 635640.

2. Greene, D. A., Lattimer, S. A. \& Sima, A. A. F. (1987) Sorbitol, phosphoinositides, and sodium-potassium-ATPase in the pathogenesis of diabetic complications. N. Engl. J. Med. 316, 599-606.

3. Corder, C. N., Collins, J. G., Brannan, T. S. \& Sharma, J. (1977) Aldose reductase and sorbitol dehydrogenase distribution in rat kidney. J. Histochem. Cytochem. 25, 1-8.

4. Sands, J. M., Terada, Y., Bernard, L. M. \& Knepper, M. A. (1989) Aldose reductase activities in microdissected rat renal tubule segments. Am. J. Physiol. 256, F563-F569.

5. Beyers-Mears, A., Ku, L. \& Cohen, M. P. (1984) Glomerular polyol accumulation in diabetes and its prevention by oral sorbinil. Diabetes 33, 604-607.

6. Bank, N., Mower, P., Aynedjian, H. S., Wilkes, B. M. \& Silverman, S. (1989) Sorbinil prevents glomerular hyperfusion in diabetic rats. Am. J. Physiol. 256, F1000-F1006.

7. Bagnasco, S., Balaban, R., Fales, H. M., Yang, Y. \& Burg, M. (1986) Predominant osmotically active organic osmolytes in rat and rabbit inner medullas. J. Biol. Chem. 261, $5872-5877$

8. Wirthensohn, G., Lefrank, S., Schmolke, M. \& Guder, W. G. (1989) Regulation of organic osmolyte concentrations in tubules from rat inner medulla. Am. J. Physiol. 256, F128-F135.

9. Yancey, P. H. \& Burg, M. B. (1989) Distribution of major organic osmolytes in rabbit kidneys in diuresis and antidiuresis. Am. J. Physiol. 257, F602-F607.

10. Beck, F. X., Dörge, A., Thurau, K. \& Guder, W. G. (1990) Cell osmoregulation in the countercurrent system of the renal medulla: the role of organic osmolytes. In: Cell Volume Regulation, Comparative Physiology (Beyenbach, K. W., ed.) Vol. 4 pp. 132-158, S. Karger, Basel.

11. Cowley, Jr B. D., Ferraris, J. D., Carper, D. \& Burg, M. B. (1990) In vivo osmoregulation of aldose reductase mRNA, protein, and sorbitol in renal medulla. Am. J. Physiol. 258, F154-F161.

12. Chauncey, B., Leite, M. V. \& Goldstein, L. (1988) Renal sorbitol accumulation and associated activities in diabetes. Enzyme 39, 231-234.

13. Grunewald, R. W. \& Kinne, R. K. H. (1989) Sorbitol metabolism in inner medullary collecting duct cells of diabetic rats. Pflügers Arch. 414, 346-350.

14. Wirthensohn, G. \& Guder, W. G. (1985) Glycerophosphorylcholine. In: Methods of Enzymatic Analysis (Bergmeyer, H. U., Bergmeyer, J. \& Grassl, M., eds.) Vol. VIII, pp. 112-116, Verlag Chemie, Weinheim.

15. Beutler, H. O. (1984) Xylitol. In: Methods of Enzymatic Analysis (Bergmeyer, H. U., Bergmeyer, J. \& Grassl, M., eds.) Vol. VI, pp. 484-490, Verlag Chemie, Weinheim.

16. Dolhofer, R. \& Wieland, O. H. (1987) Enzymatic assay of myo-inositol in serum. J. Clin. Chem. Clin. Biochem. 25, $733-736$.
17. Vormbock, R. (1984) D-Glucose: UV-method with glucose dehydrogenase. In: Methods of Enzymatic Analysis (Bergmeyer, H. U., Bergmeyer, J. \& Grassl, M., eds.) Vol. VI, pp. 172-178, Verlag Chemie, Weinheim.

18. Schleicher, E. \& Wieland, O. H. (1981) Specific quantitation by HPLC of protein (lysine) bound glucose in human serum albumin and other glycolysated proteins. J. Clin. Chem. Clin. Biochem. 19, 81-87.

19. Hofmann, W. \& Guder, W. G. (1989) A diagnostic programme for quantitative analysis of proteinuria. J. Clin. Chem. Clin. Biochem. 27, 589-600.

20. Sachs, L. (1983) Angewandte Statistik, pp. 230-246, Springer Verlag, Berlin.

21. Schmolke, M., Beck, F. X. \& Guder, W. G. (1989) Effect of antidiuretic hormone on renal organic osmolytes in Brattleboro rats. Am. J. Physiol. 257, F732-F737.

22. Schmolke, M., Bornemann, A. \& Guder, W. G. (1990) Polyol determination along the rat nephron. Biol. Chem. Hoppe-Seyler 371, 909-916.

23. Garty, H., Furlong, T. J., Ellis, D. E. \& Spring, K. R. (1991) Sorbitol permease: an apical membrane transporter in cultured renal papillary epithelial cells. Am. J. Physiol. 260, F650-F656.

24. Moriyama, T., Garcia-Perez, A. \& Burg, M. B. (1990) Factors effecting the ratio of different organic osmolytes in renal medullary cells. Am. J. Physiol. 259, F847-F858.

25. Ullrich, K. H. \& Pehling, G. (1956) Über das Vorkommen von Phosphorverbindungen in verschiedenen Nierenabschnitten und Änderung ihrer Konzentration in Abhängigkeit vom Diuresezustand. Pflügers Arch. 262, 551 - 561 .

26. Yancey, P. H. (1988) Osmotic effectors in kidneys of xeric and mesic rodents: corticomedullary distributions and changes with water availability. J. Comp. Physiol. B 158 , $369-380$.

27. Heilig, C. W., Stromski, M. E. \& Gullans, S. R. (1989) Methylamine and polyol responses to salt loading in renal inner medulla. Am. J. Physiol. 257, F1117-F1123.

28. Loy, A., Lurie, K. G., Ghosh, A., Wilson, J. M., MacGregor, L. C. \& Matschinsky, F. M. (1990) Diabetes and the myo-inositol paradox. Diabetes 39, 1305-1312.

29. Hammerman, M., Schachter, B. \& Daughady, W. (1980) myo-Inositol transport in renal brush border vesicles and its inhibition by D-glucose. Am. J. Physiol. 239, F113F120.

30. Yancey, P. H., Russel, G., Haner, G. \& Freudenberger, T. H. (1990) Effects of an aldose reductase inhibitor on organic osmotic effectors in rat renal medulla. Am. J. Physiol. 259, F733-F738.

Prof. Dr. W. G. Guder

Institut für Klinische Chemie

Krankenhaus München-Bogenhausen

Englschalkingerstraße 77

W-8000 München 81

Deutschland 


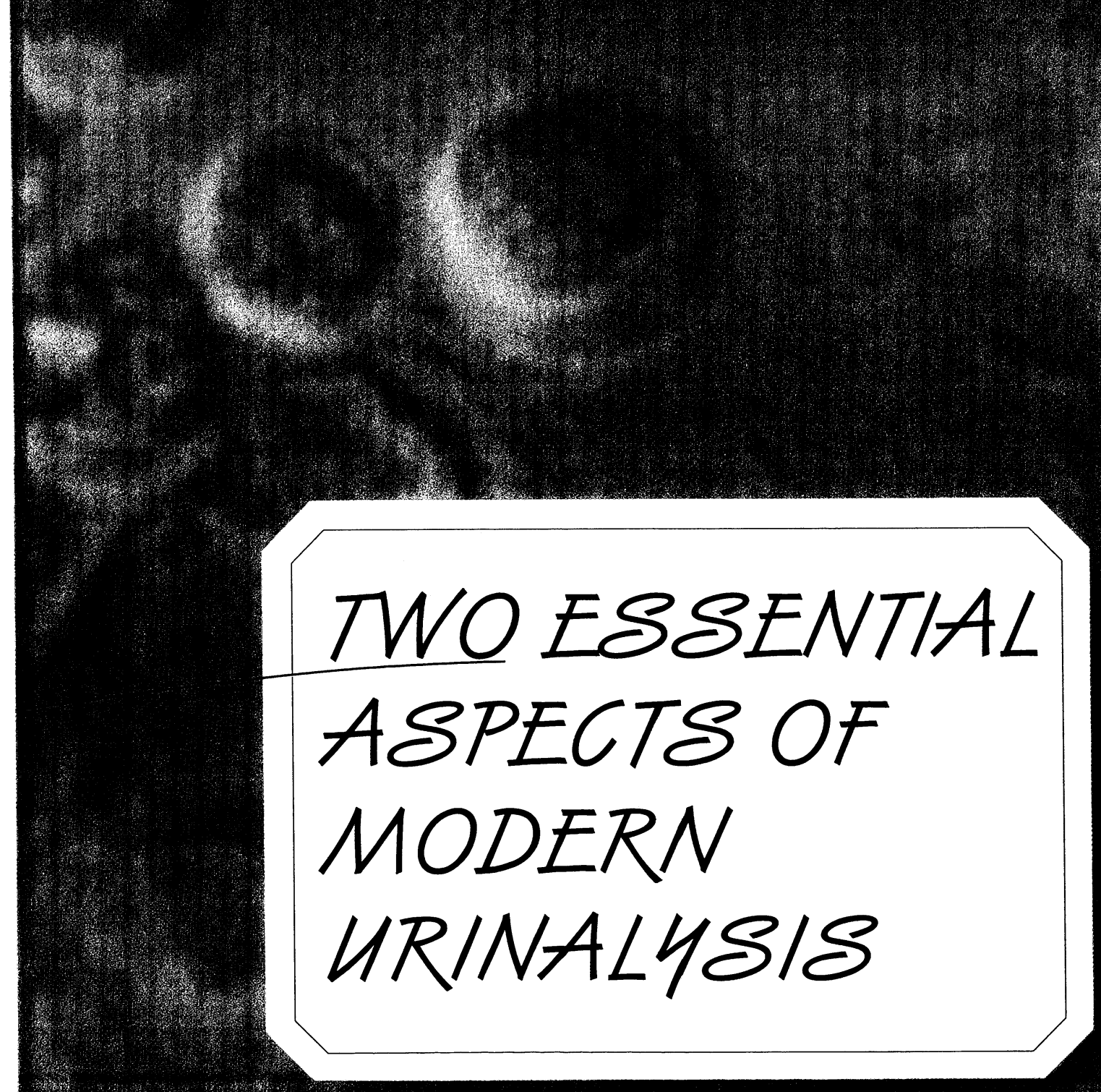

TWO ESSENTIAL ASPECTS OF MODERN URINALYSIS 
Routine urinalysis with a system concept

tailor-made to user requirements

\section{Miditron $^{\circledR}$}

The complete solution for your urinalysis workplace
- test strips of high, consistent quality

- new analytical instrumentation based on flexible technology
An ideal synthesis of practical benefits: $\checkmark$ User-friendly operation

$\checkmark$ Flexible sample identification

$\checkmark$ Reliable test-strip measurement

$\checkmark$ Efficient sediment examination

$\checkmark$ High-performance printer

$\checkmark$ Easy cleaning and maintenance

$\checkmark$ Numerous possibilities to connect to peripheral instruments

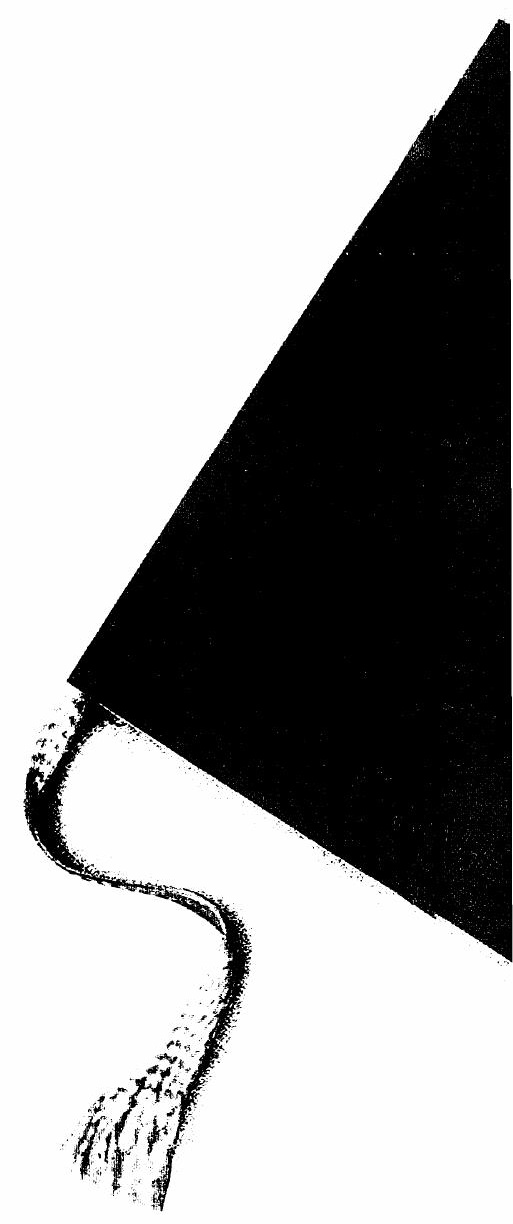

Obtain the parameters you reipuin ...on the Miditron ${ }^{\circledR}$

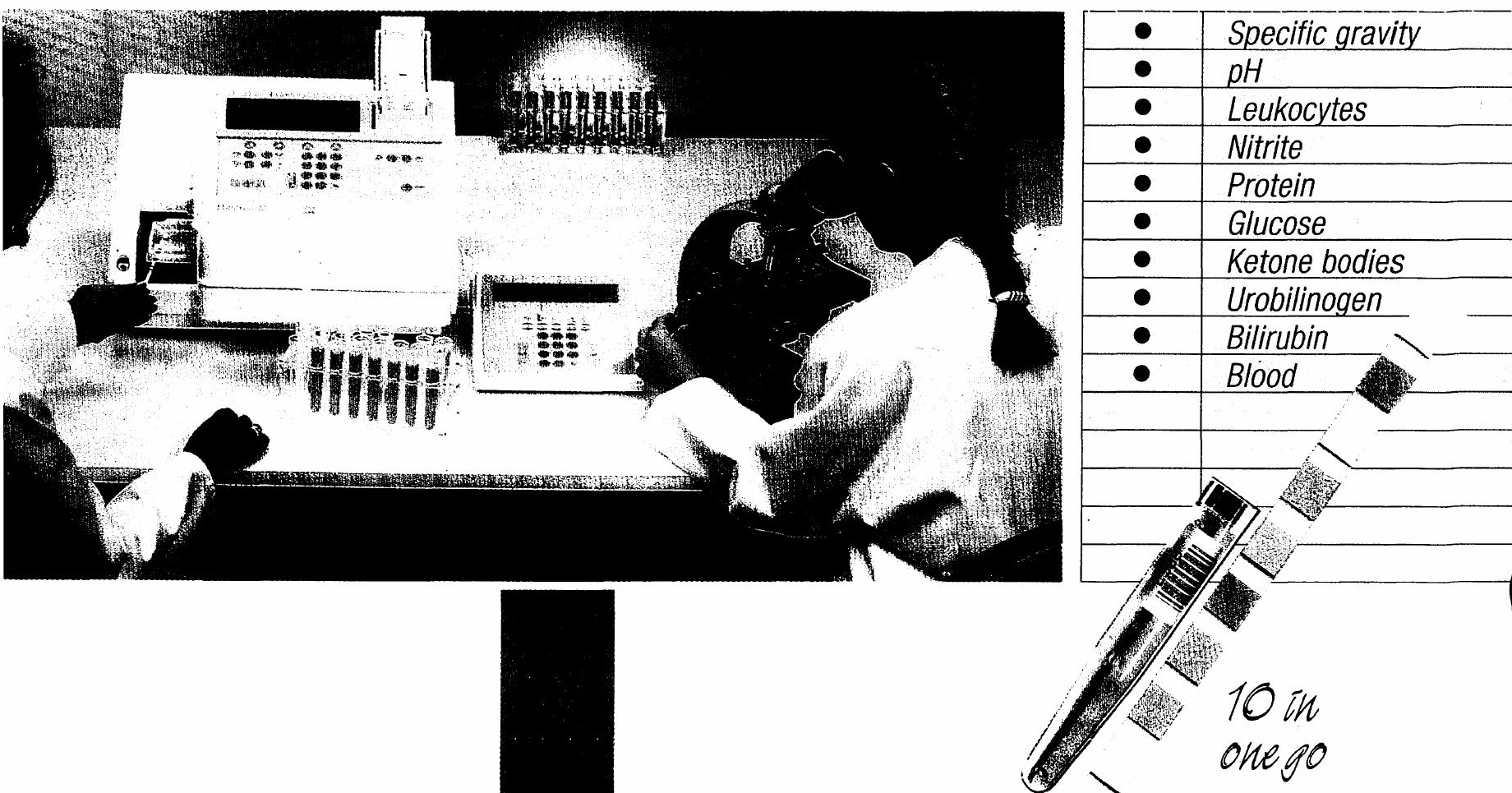


Differential diagnosis of urine samples with fully selective analytical systems

BM/Hitachi 911/747

Proven, innovative

systems based on sophisticated technology
- high degree of flexibility and reliability

- optimized reagent convenience
Selective analvzers

with distinct performance characteristics: n thee BM/Hitachi 911/747

\begin{tabular}{l|l|}
\hline$\bullet$ & Albumin (MAU) \\
\hline$\bullet$ & $\alpha$-amylase EPS \\
\hline$\bullet$ & Pancreatic $\alpha$-amylase EPS \\
\hline$\bullet$ & Calcium \\
\hline$\bullet$ & Creatinine PAP \\
\hline$\bullet$ & Creatinine Jaffé \\
\hline & Urea \\
\hline$\bullet$ & Glucose HK \\
\hline$\bullet$ & Uric acid PAP \\
\hline & Potassium ${ }^{2}$ \\
$\bullet$ & Magnesium \\
$\bullet$ & $\beta-$ NAG $^{2}$ \\
$\bullet$ & Sodium \\
\hline & Inorganic phosphatase \\
\hline & \\
\hline
\end{tabular}

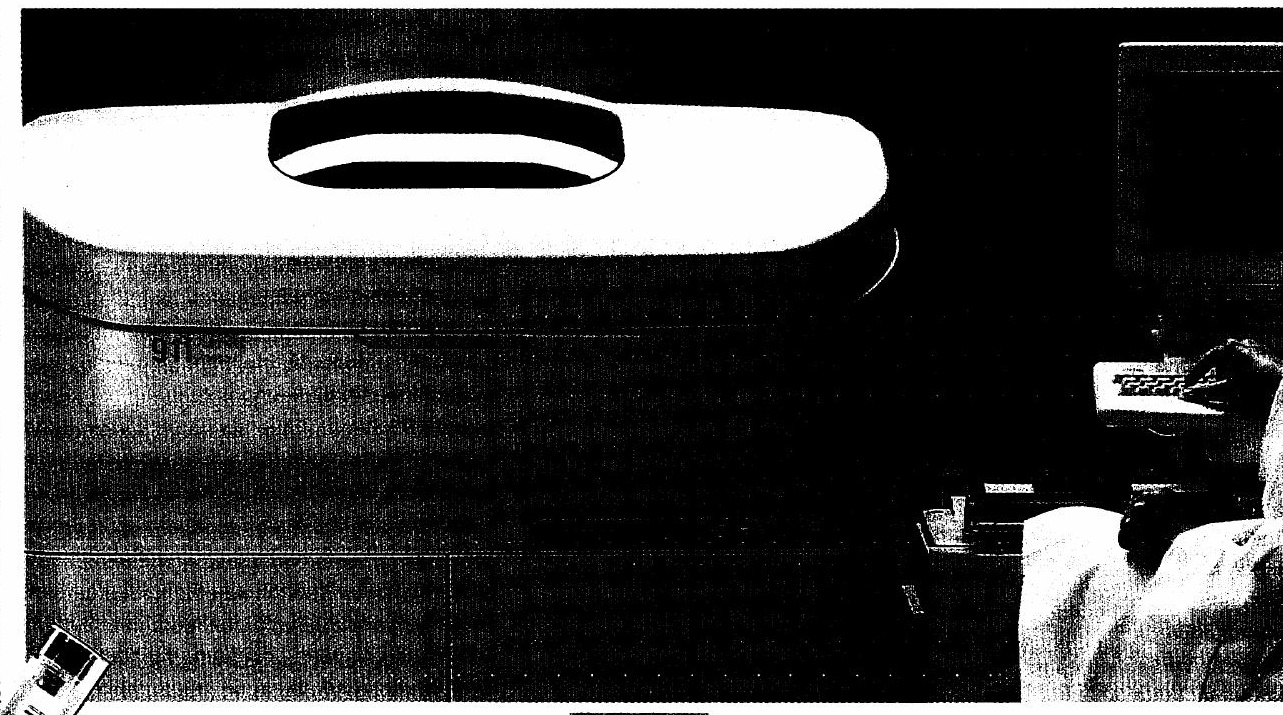

Sodium and potassium assays using

$\checkmark$ Fully selective processing of urine samples

$\checkmark$ Urine determinations using the same reagent and channel as for serum

$\checkmark$ Automatic sample predilution on the BM/Hitachi 911

$\checkmark$ Continually expanding range of tests now including assays for MAU ${ }^{1}$ and $\beta-N A G$

$\checkmark$ Reporting of results based on separa normal values for urine and serum

\section{All from}

one 
